\title{
PATTERN OF MORPHOMETRIC DIFFERENTIATION AMONG THREE POPULATIONS OF SNOWTROUT, SCHIZOTHORAX PLAGIOSTOMUS (ACTINOPTERYGII: CYPRINIFORMES: CYPRINIDAE), FROM KASHMIR HIMALAYA USING A TRUSS NETWORK SYSTEM
}

\author{
Farooq A. MIR ${ }^{1}$, Javaid I. MIR ${ }^{2 *}$, Rabindar S. PATIYAL ${ }^{2}$, and Suresh CHANDRA ${ }^{2}$ \\ ${ }^{1}$ Department of Zoology, University of Kashmir, India \\ ${ }^{2}$ Directorate of Coldwater Fisheries Research, Bhimtal, India
}

Mir F.A., Mir J.I., Patiyal R.S., Chandra S. 2013. Pattern of morphometric differentiation among three populations of snowtrout, Schizothorax plagiostomus (Actinopterygii: Cypriniformes: Cyprinidae), from Kashmir Himalaya using a truss network system. Acta Ichthyol. Piscat. 43 (4): 277-284.

\begin{abstract}
Background. The fishes of the genus Schizothorax, commonly known as snowtrouts, are a group of species that are difficult to distinguish based on external morphological characters. One of them, Schizothorax plagiostomus Heckel, 1838, is a commercially important freshwater fish with wide distribution along the Himalayan foothills. However, recent observations have indicated drastic declines and change in the stock structure of this species in many areas of its range due to the introduction of exotics, water impoundments (dams), and overfishing. Therefore, this study was intended to verify the variation in stock structure of this species in Kashmir Himalaya by using morphological characters generated by truss network analysis.

Materials and methods. A total number of 189 specimens of S. plagiostomus were collected from three different water bodies of Kashmir Himalaya. A truss network was constructed by interconnecting 12 landmarks to form a total of 30 distance variables extracted from digital images of samples using tpsDig2 and PAST software platforms. The transformed truss measurements were subjected to principal component analysis, discriminant function analysis, and univariate analysis of variance for identification of different parameters responsible for population discrimination among these water bodies.

Results. The principal component analysis generated nine components explaining $86.4 \%$ of total variance in samples. The step-wise discriminant function analysis retained two variables that significantly discriminated the populations. These two variables showed significant variation in head region, body depth, and caudal peduncle region of fish. Using these variables, $98.4 \%$ of the original groups were classified into their correct samples and 93.7\% of cross-validated groups omitting one procedure were classified into their correct samples.

Conclusion. This study has provided basic information about morphometric variation of S. plagiostomus, which could be indicative of the underlying stock structure of the species. A clear phenotypic divergence among S. plagiostomus samples revealed the existence of three differentiated groups viz., the Dal Lake population, the Jhelum River, and the Lidder River populations in Kashmir Himalaya. This study should be considered in fisheries management and commercial exploitation of this species and any stock enhancement program.
\end{abstract}

Keywords: Schizothorax plagiostomus, landmark method, shape variation, box-truss, Western Himalaya, India

\section{INTRODUCTION}

Many freshwater fish species are currently threatened by direct and indirect influence of human activities, such as habitat destruction and fragmentation (Mir et al. 2013b). Construction of dams across rivers in particular affects fish movements, which may restrict the gene flow and lead to differentiation of populations (Meldgaard et al. 2003). The anthropogenic disturbances are likely to alter the genetic diversity within populations and genetic differentiation between populations (Yamamoto et al. 2004). It has been suggested that fragmentation of river ecosystems may result in the alteration of migration patterns among fish populations (Jager et al. 2001), producing 'genetic stocks' that are reproductively isolated units and are genetically different from other stocks (Carvalho and Hauser 1994).

The long-term isolation of populations and interbreeding can lead to morphometric variations between populations, and this morphometric variation can provide a basis for population differentiation. Morphometric differences among stocks of a species are recognized as an important tool for evaluating the population structure and as a basis for identifying stocks (Turan 1999). Although these characters may be influenced by environmental conditions, they can be as valuable in indicating stock discreteness

\footnotetext{
* Correspondence: Dr Javaid I. Mir, Directorate of Coldwater Fisheries Research, Bhimtal- 263136, India, phone (mobile): +919956971175, e-mail: r.javaid@rediffmail.com.
} 
as other, more genetically related, features (Ihssen et al. 1981, Szlachciak 2005). There are many well documented studies that provide evidence for stock discrimination based on traditional morphometric characters (Quilang et al. 2007, Więcaszek et al. 2007, Bektas and Belduz 2009). However, a new system of morphometric measurements called the truss network system, constructed with the help of landmark points, has been increasingly used for stock identification (Mir et al. 2013b).

The fishes of subfamily Schizothorcinae belonging to family Cyprinidae are commonly known as snowtrouts. A total of 68 species of this subfamily are recorded worldwide (He and Chen 2006). In India, snowtrouts are distributed in the cold waters of Jammu and Kashmir (Sunder and Bhagat 1979), Assam and Eastern Himalayas through Bhutan and Sikkim at an altitude of 1180-3000 m above mean sea level (AMSL) (Chandra et al. 2012). Their inherent biological features, such as short growth period and slow growth to maturity are the main constraints hindering their growth and population increase (Khan and Sabah 2013). The genus Schizothorax consists of a group of species that are remarkably similar in general morphology. These species are often the most difficult to distinguish based on external morphological characters across Indian Himalaya (Mir et al. 2013a). The taxonomy of these fishes has been studied from time to time (Negi and Negi 2010, Mir et al. 2013b) but a clear picture of the status of these fishes has not been available till recently in a consolidated form (Mir et al. 2013a).

Schizothorax plagiostomus Heckel, 1838 is a commercially important freshwater herbivorous snowtrout species. It inhabits the reservoirs of Central Asia and Eastern Persia in the West to the far reaches of the Mekong and Yangtzekiang in the East (Ganai et al. 2011). The IUCN status of this species has not been evaluated to date (Anonymous 2012). This species thrives in rivers, streams and attains the maximum length of $41.5 \mathrm{~cm}$ (Khan and Sabah 2013). It has a strong resemblance with Schizothorax richardsonii (Gray, 1832) and is often difficult to distinguish from it (Pandey and Nautiyal 1997). Although, S. plagiostomus is widely distributed along the Himalayan foothills, but recent observations have indicated drastic declines in many areas of its range due to the introduction of exotics, damming, and overfishing (Ganai et al. 2011). Therefore, presently reported investigation on stock identification of $S$. plagiostomus through the truss network analysis, based on morphometric characteristics, was undertaken as a step towards the successful development and management of this species in Kashmir Himalaya.

\section{MATERIALS AND METHODS}

Study areas. The Indian Himalayas are drained by 19 main rivers among which three major river systems i.e., Ganga, Indus, and Brahmaputra are the largest. The Indus River system is the longest; it starts from Western Himalaya (160 $000 \mathrm{~km}^{2}$ ) and consists of five rivers (Mir et al. 2013a). River Jhelum is the tributary of the Indus
River and flows in the Western Himalayan region of India. It has a total length of about $813 \mathrm{~km}$, and originates from Verinag Spring in the southeastern part of the valley of Kashmir in India. The Lidder River is the second largest tributary of river Jhelum and is a $73 \mathrm{~km}$ long river in the Kashmir region of India. Its source (Kolhoi Glacier) is located at a height of $4653 \mathrm{~m}$ AMSL (Fig. 1). These are the two least explored rivers of India. The Dal Lake has been an important fishery resource to the people of the Kashmir valley since ancient times (Shafi and Yousuf 2012). It is a shallow open drainage type water body spread over an area of $11.4 \mathrm{~km}^{2}$.

Sample collection and digitization. A total of 189 Schizothorax plagiostomus specimens were collected from two different rivers (Jhelum and Lidder) and one lake (Dal Lake) in the Kashmir Valley by using different fishing gears (cast nets and gill nets) from January 2011 to December 2012 and analyzed for morphometric variations. The specimens of $S$. plagiostomus were obtained before breeding season and after spawning period to avoid any bias of size difference. The mesh size of the fishing gears was especially designed for the capture of large sized fishes to avoid any fingerling and fry capture. The location of sampling sites, river-wise number of samples analyzed, GPS coordinates, and length range statistics of S. plagiostomus are presented in Table 1. Sampled specimens were first cleansed in running water, drained and placed on a flat platform with graph paper as a background, which was used for calibrating the coordinates of the digital images. Each individual was labelled with a specific code for identification. A Cyber shot DSCW300 digital camera (Sony, Japan) was used to capture the digital images, which provided a complete archive of body shape and allowed a repeat of the measurements when necessary (Cadrin and Friedland 1999). After image capture, each fish was dissected for sex determination by macroscopic examination of the gonads. The gender was used as the class variable in ANOVA to test for significant differences in morphometric characters, if any, between male and female $S$. plagiostomus.

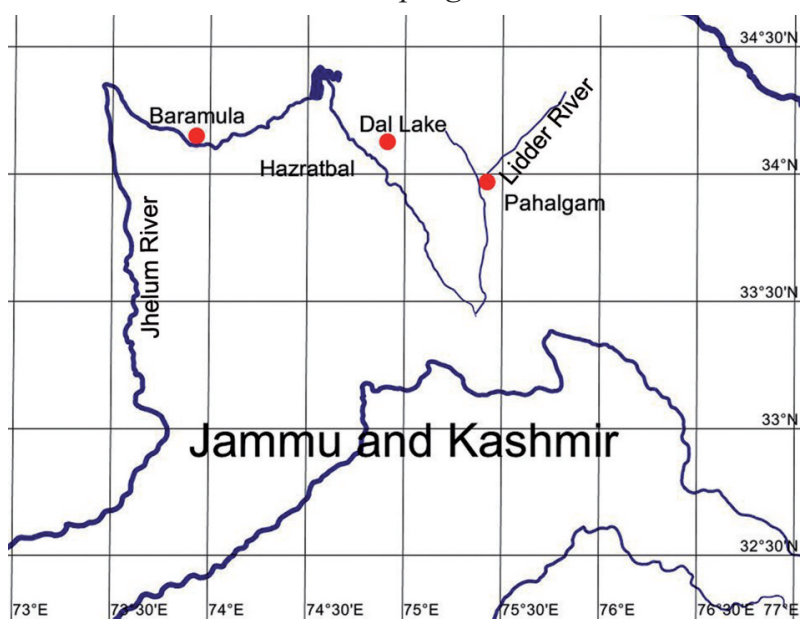

Fig. 1. Sampling sites of Schizothorax plagiostomus on two rivers (Jhelum and Lidder) and a lake (Dal Lake) of Kashmir Himalaya in India 
Laboratory procedure. The truss-network protocol used for S. plagiostomus in this study was based on 12 landmarks, which were selected only for this particular fish species ( $1=$ tip of snout, $2=$ frontal bone end; $3=$ dorsal fin origin; 4 = dorsal fin end; $5=$ caudal peduncle dorsal border; $6=$ lateral line end; $7=$ caudal peduncle ventral border; $8=$ anal fin origin; $9=$ pelvic fin origin; $10=$ pectoral fin (ventral origin); 11= opercular posterior edge; 12 = eye posterior edge.) The truss network was constructed by interconnecting the landmarks to form a total of 30 measurements (Fig. 2). The extraction of truss distances from the digital images of specimens was conducted using a linear combination of three software platforms: tpsUtil, tpsDig2 v2.1 (Rohlf unpublished ${ }^{*}$ ) and Paleontological Statistics (PAST; Hammer et al. 2001). A box truss of 30 lines connecting these landmarks was generated for each fish to represent the basic shape of the fish (Strauss and Bookstein 1982). All measurements were transferred to a spreadsheet file (Excel $\left.{ }^{\circledR} 2007\right)$, and the $X-Y$ coordinate data transformed into linear distances (using the Pythagorean Theorem) for subsequent analysis (Turan 1999).

Multivariate data analysis. As most shape measurements are in some way related to size, any heterogeneity in the size across the samples would result in heterogeneity in the shape, but without providing information on differences in body proportions among populations (Reist 1985). Several univariate and multivariate analyses can be used to remove the size effect of the samples, such as regression analysis, allometric methods, multiple group principal component analysis, etc. The allometric methods are a significant help in achieving the size and shape separation and reasonably meet the statistical assumption (Swain and Foote 1999). Significant correlations were observed between size and morphometric characters of the samples. All measurements were standardized following Elliott et al. (1995), to eliminate any variation resulting from allometric growth. $M_{a d j}=M\left(L_{s} \cdot L_{o}{ }^{-1}\right)^{b}$

where, $M_{a d j}$ is the size adjusted measurement, $M$ is the original measurement, $L_{s}$ is the overall mean of the standard length (SL) for all fish from all samples in each analysis and $L_{o}=\mathrm{SL}$ of the fish. Parameter $b$ was estimated for each character from the observed data as the slope of the regression of $\log M$ on $\log L_{o}$. The transformed data were checked for efficiency by testing the significance of the correlation between the transformed variables and standard length. Standard length was excluded from the final analysis.

The results derived from the allometric method were confirmed by testing the significance of the correlation between the transformed variables and standard length (Mir et al. 2013b). Univariate analysis of variance (ANOVA) was performed for 30 morphometric characters to evaluate the significant difference among the three locations. The transformed data were subjected to principal component analysis and discriminant analysis to examine any phenotypic differences between the populations. The eigenvectors and eigenvalues were obtained from the covariance

Sample parameters of snowtrout, Schizothorax plagiostomus, collected from three sites

Table 1 at the Kashmir Valley

\begin{tabular}{lccc}
\hline & \multicolumn{3}{c}{ Study site } \\
\cline { 2 - 4 } Parameter & Dal Lake (Hazratbal) & Jhelum (Baramulla) & Lidder (Pahalgam) \\
\hline Sample size $(n)$ & 58 & 63 & 68 \\
TL range $[\mathrm{mm}]$ & $137-395$ & $126-404$ & $152-375$ \\
Latitude & $34^{\circ} 5^{\prime} 24^{\prime \prime} \mathrm{N}$ & $34^{\circ} 11^{\prime} 53^{\prime \prime} \mathrm{N}$ & $34^{\circ} 0^{\prime} 45^{\prime \prime} \mathrm{N}$ \\
Longitude & $74^{\circ} 47^{\prime} 24^{\prime \prime} \mathrm{E}$ & $74^{\circ} 21^{\prime} 49^{\prime \prime} \mathrm{E}$ & $75^{\circ} 18^{\prime} 56^{\prime \prime} \mathrm{E}$ \\
Altitude AMSL $[\mathrm{m}]$ & 1584 & 1581 & 2130 \\
\hline
\end{tabular}

AMSL $=$ above mean sea level.

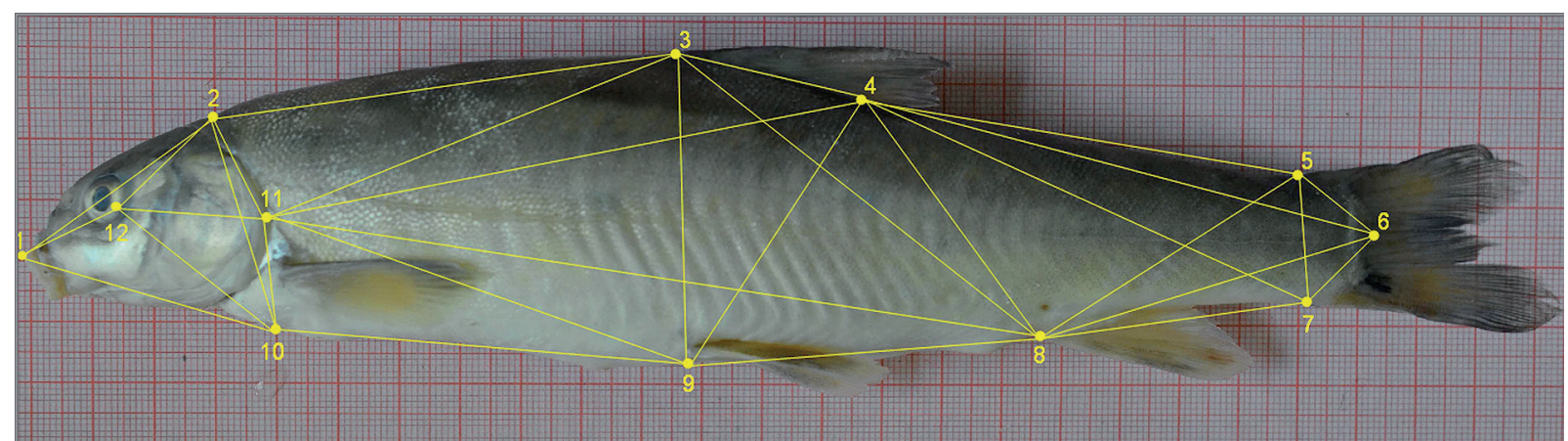

Fig. 2. Schematic image of Schizothorax plagiostomus depicting the 12 landmarks and associated box truss; $1=$ tip of snout, $2=$ frontal bone end; $3=$ dorsal fin origin; $4=$ dorsal fin end; $5=$ caudal peduncle dorsal border; $6=$ lateral line end; $7=$ caudal peduncle ventral border; $8=$ anal fin origin; $9=$ pelvic fin origin; $10=$ pectoral fin $($ ventral origin); $11=$ opercular posterior edge; 12 = eye posterior edge

\footnotetext{
${ }^{*}$ Rohlf F.J. 2006. tpsDig2, Version 2.1. State University of New York, Stony Brook. http://life.bio.sunysb.edu/morph.
} 
matrix in the principal component analysis, which allowed the largest part of the variance of original variables in a low number of factors. This analysis enabled the evaluation of the relation between the populations by means of proximity in the space defined by the components. A stepwise procedure was used to reduce the number of variables in order to meet the requirement of the reduced set of characters for the discriminant function analysis. The ability of the phenotypes to discriminate between populations was assessed by a cross-validation test. This required the removal of one individual from the original matrix; a discriminant analysis was carried out with the remaining observations and then used to classify the omitted individuals. The basis for differentiation among samples was based on the percentage of correctly classified (PCC) and incorrectly classified fish. The measurement of the morphological distinctness of the population was given by the percentage of correctly classified individuals. The degree of intermingling among the populations was indicated by the number of misclassified individuals. All statistical analyses were carried out using MS EXCEL ${ }^{\circledR}$ and SPSS $^{\circledR}$ (version 16.1.0).

Ethical issues. The presently reported study has been carried out in accordance with the country's regulations related to animal care and animal protection.

\section{RESULTS}

Descriptive data for the length range, sample number, GSI coordinates and altitude of different sampling sites is shown in Table 1. There was no significant correlation between any of the transformed measured morphometric variables and standard length $(P>0.001)$, indicating that the size effect was successfully removed.

Univariate analysis of variance showed that all the 30 morphometric characters were significantly different among samples $(P<0.001)$. These are particularly noticeable for the body depth distances and measurements of the caudal peduncle region. The morphometric characters between both sexes did not differ significantly $(P>0.05)$, hence the data for both sexes were pooled for all subsequent analyses. Principal component analysis of 30 morphometric measurements extracted nine factors with eigenvalues $>1$, explaining $86.4 \%$ of the total variance. PC1 accounted for $26.0 \%$ of total variance and was positively correlated to some variables and negatively correlated with others, showing that there is variation due to body shape. Similarly, another eight components showed different degrees of variation (Table 2). The high component loadings were from the characters which mostly contributed to head region, body depth and the caudal peduncle region (Table 2).

Wilks $\lambda$ tests of discriminant analysis indicated significant differences in morphometric characters of all populations $(P<0.001)$. Forward stepwise discriminant analysis of the 30 variables produced two discriminating functions. The first canonical discriminant function of the discriminant analysis explained $99.9 \%$ of the total variance while the second one accounted for $0.1 \%$ of the total variance. The morphometric truss measurements, 1-10, 2-3,
2-10, 3-4, 3-11, 4-6, 4-7, 5-8, 8-11, 9-10, and 10-11 contributed to DF1 while other characters contributed to DF2 (Table 3), showing that these characters were the most important in distinguishing of the populations. The DF1 vs. DF2 plot explained $100 \%$ of total variance among the samples and showed significant distinction among Schizothorax plagiostomus groups from the Kashmir Himalaya (Fig. 3). Discriminant function analysis showed $98.4 \%$ correct classification of individuals into their original populations, and the cross-validation test results were comparable to the results obtained from PCC. The percentage of correctly classified fishes was $100 \%$ in Dal Lake and Lidder River, whereas Jhelum population showed slight $(4.8 \%)$ intermingling with Lidder River population (Table 4). The DFA segregation was also confirmed by PCA, where the graphs of PC1 and PC2 scores for each sample revealed clear demarcation among three populations of $S$. plagiostomus.

The most prominent interpopulation differences in separate morphometric features were observed for three characters. The percentage of head depth, maximum body depth and minimum body depth in relation to standard length of the fish showed that the riverine specimens are somewhat different from the specimens of Dal Lake. These three characters were smaller in riverine specimens as compared to Dal Lake specimens (Table 5).

\section{DISCUSSION}

The observations of truss-based morphometrics indicated that Schizothorax plagiostomus of Dal Lake demonstrates differences in the complexes of morphometric features from the Jhelum and Lidder Rivers of Kashmir Valley. Such indications of stock structure arise from consideration of the first and second factors. This study showed that the variation is evident in the head region (1-2, 1-10, 2-10, 2-1, 2-12, and 11-12), middle part of the body (3-8, 3-9, 3-1, 4-8, 4-9, and 4-11), and the caudal region (5-6, 5-7, and 5-8), which were useful for the stock separation. The variation in the caudal region of specimens from the three water bodies could be a consequence of phenotypic plasticity in response to uncommon hydrological conditions.

The differences in the morphometry of Schizothorax plagiostomus between these two rivers could also be because of their geographic and topographic differences. The Baramulla site on Jhelum River is more than $100 \mathrm{~m}$ wide with extensive human influences towards upstream whereas, the Pahalgam site on Lidder River is narrow $(<50 \mathrm{~m})$ with least man-made interruptions towards upstream. The Dal Lake is a lentic water body and the two rivers have more turbulent water condition (Khan and Sabah 2013). Within this scenario, these pressures can result in more resistance on fish body during the swimming. The riverine specimens of $S$. plagiostomus showed lower body depth, sharper snout and more spindle-shaped body than specimens of Dal Lake. Moreover, such differences could be partly explained by dietary shifts, which induce changes on the body shape influencing prey selec- 
tion and catch efficiency (Keast 1978). However, in a cyprinid, Indian major carp, Labeo rohita (Hamilton, a detailed follow-up study is required to reveal whether it 1822), from six drainages of Ganges basin differing in is purely environmental or result of genotype by environ- current velocity. Khan et al. (2013) have also found varimental interaction. For example, Bagherian and Rahmani ation in the caudal area of a Channidae fish, Channa (2009) also reported that high water velocity leads to slen- punctata (Bloch, 1793), from the Ganges basin in India.

der body shape in a Caspian cyprinid, Alburnus chal- Different factors such as food availability, salinity, or coides (Güldenstädt, 1772). Thus, the different current temperature may affect the morphometry of fish and culpattern of these water bodies may be playing an important minate into the parting of fish populations (Palma and role in modifying the morphometry of S. plagiostomus Andrade 2002). Differentiation between samples from among these water bodies. A study by Mir et al. (2013b) adjacent stations may be due to the geographic isolation demonstrated morphological variation in the caudal area of stations by water impoundments. Obstructing the

Table 2

Component loadings of nine principal components for truss morphometric characters in snowtrout, Schizothorax plagiostomus, collected from the Indus basin

\begin{tabular}{|c|c|c|c|c|c|c|c|c|c|}
\hline \multirow[b]{2}{*}{ Truss } & \multicolumn{9}{|c|}{ Component } \\
\hline & $\begin{array}{c}\mathrm{PC} 1 \\
(26.0 \%)\end{array}$ & $\begin{array}{c}\text { PC2 } \\
(13.6 \%)\end{array}$ & $\begin{array}{c}\text { PC3 } \\
(11.2 \%)\end{array}$ & $\begin{array}{c}\text { PC4 } \\
(8.9 \%)\end{array}$ & $\begin{array}{c}\text { PC5 } \\
(8.1 \%) \\
\end{array}$ & $\begin{array}{c}\text { PC6 } \\
(6.2 \%) \\
\end{array}$ & $\begin{array}{c}\text { PC7 } \\
(4.7 \%) \\
\end{array}$ & $\begin{array}{c}\text { PC8 } \\
(4.3 \%) \\
\end{array}$ & $\begin{array}{c}\text { PC9 } \\
(3.4 \%) \\
\end{array}$ \\
\hline $1-2$ & -0.895 & 0.016 & 0.050 & 0.012 & 0.025 & 0.150 & -0.094 & 0.113 & 0.021 \\
\hline $1-10$ & -0.884 & -0.043 & 0.230 & -0.168 & -0.041 & 0.071 & -0.098 & -0.018 & 0.184 \\
\hline $1-12$ & -0.942 & 0.071 & 0.155 & 0.020 & -0.009 & 0.138 & -0.078 & 0.044 & 0.018 \\
\hline $2-3$ & -0.902 & 0.019 & 0.174 & -0.023 & 0.222 & 0.111 & -0.022 & 0.066 & -0.017 \\
\hline $2-10$ & -0.487 & 0.213 & 0.650 & 0.397 & -0.167 & 0.126 & 0.058 & -0.070 & 0.048 \\
\hline $2-11$ & -0.546 & -0.001 & 0.254 & -0.277 & 0.040 & 0.213 & -0.001 & -0.142 & 0.018 \\
\hline $2-12$ & -0.689 & 0.211 & 0.069 & 0.089 & 0.114 & 0.475 & 0.093 & 0.171 & -0.250 \\
\hline $3-4$ & -0.578 & 0.189 & 0.370 & -0.092 & 0.552 & 0.026 & 0.052 & -0.144 & -0.053 \\
\hline $3-8$ & 0.352 & 0.175 & 0.527 & 0.604 & -0.219 & 0.130 & 0.185 & -0.063 & -0.065 \\
\hline $3-9$ & -0.062 & 0.075 & 0.409 & -0.083 & 0.391 & -0.577 & -0.138 & -0.374 & 0.198 \\
\hline $3-11$ & 0.574 & 0.283 & 0.490 & 0.393 & -0.027 & 0.235 & 0.173 & -0.022 & -0.102 \\
\hline $4-5$ & 0.600 & 0.420 & 0.289 & -0.185 & -0.065 & -0.192 & -0.191 & 0.291 & 0.214 \\
\hline $4-6$ & 0.535 & 0.690 & -0.242 & 0.042 & 0.109 & 0.004 & 0.313 & -0.033 & -0.082 \\
\hline $4-7$ & 0.333 & 0.472 & 0.625 & 0.345 & 0.181 & -0.059 & -0.060 & -0.175 & 0.027 \\
\hline $4-8$ & 0.429 & 0.563 & 0.251 & -0.077 & -0.230 & -0.174 & -0.215 & 0.286 & 0.256 \\
\hline $4-9$ & 0.032 & 0.571 & 0.232 & -0.221 & 0.503 & 0.060 & -0.367 & 0.209 & -0.141 \\
\hline $4-11$ & -0.010 & 0.678 & -0.562 & -0.111 & 0.254 & 0.027 & 0.270 & 0.064 & -0.091 \\
\hline $5-6$ & 0.617 & 0.282 & -0.157 & -0.127 & 0.061 & 0.475 & -0.019 & 0.145 & -0.132 \\
\hline $5-7$ & 0.323 & 0.471 & 0.048 & -0.372 & 0.503 & -0.006 & -0.179 & -0.216 & -0.171 \\
\hline $5-8$ & 0.465 & -0.221 & 0.034 & -0.340 & -0.025 & 0.309 & 0.080 & -0.635 & -0.050 \\
\hline $6-7$ & 0.443 & -0.470 & 0.338 & -0.432 & 0.274 & 0.065 & 0.298 & -0.129 & -0.084 \\
\hline $6-8$ & 0.618 & -0.419 & 0.400 & 0.010 & -0.152 & 0.256 & -0.304 & -0.006 & -0.096 \\
\hline $7-8$ & 0.382 & -0.637 & 0.518 & -0.149 & -0.087 & 0.066 & -0.108 & 0.207 & -0.142 \\
\hline $8-9$ & 0.171 & -0.441 & 0.386 & -0.187 & 0.424 & -0.201 & 0.374 & 0.446 & -0.080 \\
\hline $8-11$ & 0.225 & -0.431 & -0.163 & 0.557 & 0.587 & -0.028 & -0.059 & 0.132 & 0.015 \\
\hline $9-10$ & 0.058 & -0.502 & -0.205 & 0.487 & 0.520 & -0.281 & -0.022 & 0.063 & -0.109 \\
\hline $9-11$ & 0.098 & -0.036 & -0.444 & 0.654 & 0.224 & 0.188 & -0.400 & -0.223 & 0.147 \\
\hline $10-11$ & 0.355 & -0.121 & -0.028 & 0.100 & 0.413 & 0.613 & 0.020 & 0.108 & 0.376 \\
\hline $10-12$ & 0.316 & -0.231 & -0.081 & -0.358 & 0.200 & 0.325 & -0.067 & 0.056 & 0.524 \\
\hline $11-12$ & -0.180 & 0.139 & 0.087 & 0.160 & 0.068 & -0.043 & 0.597 & -0.037 & 0.440 \\
\hline
\end{tabular}

Measured distances are visualized in Fig. 1; Truss = truss measurement; PC = principal component; Codes for truss landmarks: $1=$ tip of snout, $2=$ frontal bone end; $3=$ dorsal fin origin; $4=$ dorsal fin end; $5=$ caudal peduncle dorsal border; $6=$ lateral line end; $7=$ caudal peduncle ventral border; $8=$ anal fin origin; $9=$ pelvic fin origin; $10=$ pectoral fin $($ ventral origin); $11=$ opercular posterior edge; $12=$ eye posterior edge. 
migration of fish populations may result in an ecological trap, allowing morphological differentiation to proceed independently (Jager et al. 2001). The Jhelum River is regulated by Mangla Dam, Rasul Barrage, and Trimmu

Table 3

Pooled within-group correlations between discriminating variables and discriminant functions of snowtrout, Schizothorax plagiostomus from the Kashmir Valley

\begin{tabular}{|c|c|c|}
\hline \multirow{2}{*}{$\begin{array}{l}\text { Truss } \\
\text { measurement }\end{array}$} & \multicolumn{2}{|c|}{ Function } \\
\hline & DF1 $(99.9 \%)$ & DF2 $(0.1 \%)$ \\
\hline $2-10$ & 0.242 & -0.032 \\
\hline $10-11$ & -0.128 & 0.031 \\
\hline $8-11$ & 0.104 & -0.048 \\
\hline $3-4$ & 0.099 & 0.034 \\
\hline $2-3$ & 0.086 & -0.068 \\
\hline $4-6$ & 0.083 & -0.010 \\
\hline $3-11$ & -0.053 & -0.033 \\
\hline $9-10$ & 0.049 & -0.030 \\
\hline $4-7$ & 0.040 & 0.021 \\
\hline $5-8$ & 0.037 & 0.009 \\
\hline $1-10$ & -0.020 & -0.003 \\
\hline $11-12$ & 0.099 & 0.438 \\
\hline $8-9$ & -0.035 & -0.350 \\
\hline $2-11$ & -0.064 & -0.248 \\
\hline $9-11$ & 0.097 & 0.189 \\
\hline $4-5$ & 0.006 & 0.178 \\
\hline $10-12$ & 0.013 & 0.178 \\
\hline $3-9$ & -0.089 & 0.169 \\
\hline $6-8$ & 0.109 & 0.164 \\
\hline $6-7$ & 0.062 & -0.162 \\
\hline $4-8$ & 0.070 & 0.147 \\
\hline $5-6$ & 0.112 & 0.132 \\
\hline $2-12$ & -0.070 & -0.132 \\
\hline $4-9$ & -0.022 & 0.128 \\
\hline $1-12$ & -0.069 & -0.091 \\
\hline $7-8$ & 0.040 & 0.089 \\
\hline $5-7$ & -0.015 & 0.061 \\
\hline $4-11$ & -0.020 & -0.033 \\
\hline $3-8$ & 0.027 & -0.031 \\
\hline $1-2$ & 0.006 & -0.009 \\
\hline
\end{tabular}

$\mathrm{DF}=$ variables ordered by size of correlation within function; Bold font denotes significant correlation between each variable and DFs.
Barrage affecting the ecosystem and causing the destruction of breeding grounds (Mir et al. 2013b). The blockage of fish movements can have a very significant impact on fish stocks by obstructing the genetic exchange (Lakra et

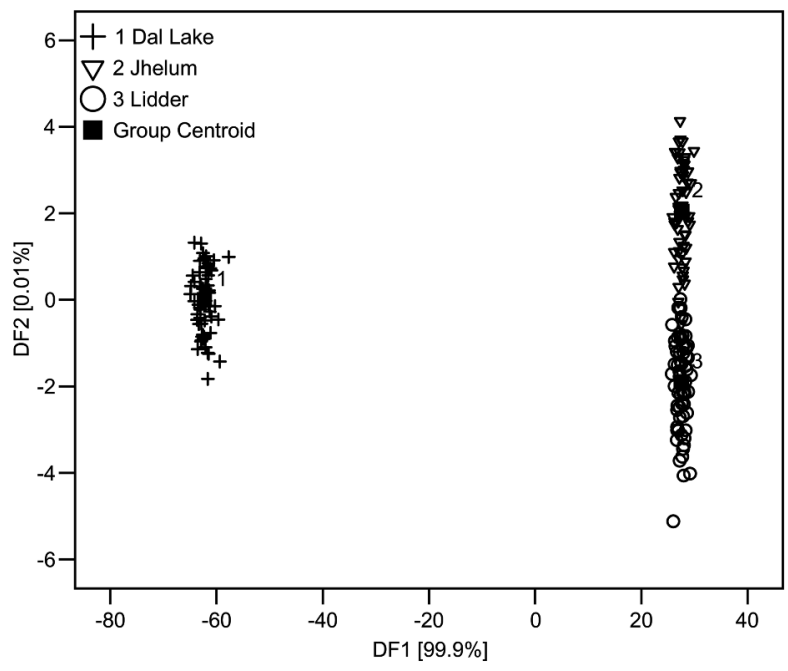

Fig. 3. Coordinate plots of three populations of Schizothorax plagiostomus by plotting first two discriminant functions from the morphometric data analysis

Table 4

Percentage of specimens classified in each (original) group and after cross validation for morphometric measurements for snowtrout, Schizothorax plagiostomus, from Kashmir Himalaya

\begin{tabular}{ccrrrr}
\hline $\begin{array}{c}\text { Group } \\
{[\%]}\end{array}$ & Water body & Dal Lake & Jhelum & Lidder & Total \\
\hline \multirow{4}{*}{ O } & Dal Lake & 100.0 & 0.0 & 0.0 & 100.0 \\
& Jhelum & 0.0 & 95.2 & 4.8 & 100.0 \\
& Lidder & 0.0 & 0.0 & 100.0 & 100.0 \\
\hline \multirow{4}{*}{ CV } & Dal Lake & 100.0 & 0.0 & 0.0 & 100.0 \\
& Jhelum & 0.0 & 87.3 & 12.7 & 100.0 \\
& Lidder & 0.0 & 5.9 & 94.1 & 100.0 \\
\hline
\end{tabular}

$\mathrm{O}=$ original, $\mathrm{CV}=$ cross-validated $(98.4 \%$ of originallygrouped cases correctly classified, $93.7 \%$ of cross-validatedgrouped cases correctly classified).

Table 5

Morphometric characters demonstrating the most prominent differences between three studied populations of snowtrout, Schizothorax plagiostomus, from Kashmir Himalaya

\begin{tabular}{lccc}
\hline \multirow{2}{*}{ Parameter } & \multicolumn{3}{c}{ Study site } \\
\cline { 2 - 4 } Head depth & Dal Lake (Hazratbal) & Jhelum (Baramulla) & Lidder (Pahalgam) \\
\cline { 2 - 4 } Maximum body depth & $35.8(28.7-43.1)$ & $27.5(18.4-35.4)$ & $30.2(25.8-40.5)$ \\
Minimum body depth & $44.7(32.4-50.3)$ & $41.9(32.0-48.6)$ & $35.2(24.0-44.9)$ \\
\hline
\end{tabular}

Values are mean and range (in brackets) expressed as \% of standard length. 
al. 2011). Also, the construction of a dam can lead to dramatic changes in the environment of a river and can particularly affect fish communities by altering feeding habits, availability of food items, growth patterns, reproductive strategies and spawning grounds (AnvariFar et al. 2011).

In conclusion, the presently reported study provides basic information about the differentiation of Schizothorax plagiostomus populations in the Kashmir Himalaya using morphometric parameters and suggests that morphometric variations observed in S. plagiostomus should be considered in its biodiversity pattern and should also be used as a preliminary step towards fisheries management and commercial exploitation of this species and any stock enhancement program. Nevertheless, future studies on determination of population structure will be elucidated using biochemical and molecular genetics methods.

\section{ACKNOWLEDGEMENTS}

The help of fishermen from the Kashmir Valley is highly acknowledged.

\section{REFERENCES}

Anonymous 2012. IUCN Red List of Threatened Species. Version 2012.1. IUCN 2012. IUCN Red List of Threatened Species. [Accessed in June 2012.]

AnvariFar H., Khyabani A., Farahmand H., Vatandoust S., AnvariFar H., Jahageerdar S. 2011. Detection of morphometric differentiation between isolated up- and downstream populations of Siah Mahi (Capoeta capoeta gracilis) (Pisces: Cyprinidae) in the Tajan River (Iran). Hydrobiologia 673 (1): 41-52. DOI: 10.1007/s10750-011-0748-7

Bagherian A., Rahmani H. 2009. Morphological discrimination between two populations of shemaya, Chalcalburnus chalcoides (Actinopterygii, Cyprinidae) using a truss network. Animal Biodiversity and Conservation 32 (1): 1-8. DOI: (Revista) ISSN 1578-665X

Bektas Y., Belduz A.O. 2009. Morphological variation among Atlantic horse mackerel, Trachurus trachurus populations from Turkish coastal waters. Journal of Animal and Veterinary Advances 8 (3): 511-517.

Cadrin S.X., Friedland K.D. 1999. The utility of image processing techniques for morphometric analysis and stock identification. Fisheries Research 43 (1-3): 129-139. DOI: 10.1016/S0165-7836(99)00070-3

Carvalho G.R., Hauser L. 1994. Molecular genetics and the stock concept in fisheries. Reviews in Fish Biology and Fisheries 4 (3): 326-350. DOI: 10.1007/BF00042908

Chandra S., Barat A., Singh M., Singh B.K., Matura R. 2012. DNA bar-coding of Indian coldwater fishes of genus Schizothorax (family: Cyprinidae) from Western Himalaya. World Journal of Fish and Marine Sciences 4 (4): 430-435. DOI: 10.5829/idosi.wjfms.2012.04.04.63136

Elliott N.G., Haskard K., Koslow J.A. 1995. Morphometric analysis of orange roughy (Hoplostethus atlanticus) off the continental slope of southern Australia. Journal of Fish Biology 46 (2): 202-220. DOI: 10.1111/j.10958649.1995.tb05962.x
Ganai F.A., Yousuf A.R., Dar S.A., Tripathi N.K., Wani S.U. 2011. Cytotaxonomic status of Schizothoracine fishes of Kashmir Himalaya (Teleostei: Cyprinidae). Caryologia 64 (4): 435-445.

Hammer Ø., Harper D.A.T., Ryan P.D. 2001. PAST: paleontological statistics software package for education and data analysis. Palaeontologia Electronica 4 (1): [Unnumbered pages without permanent formating.] http://palaeo- electronica.org/2001_1/past/issue1_01.htm.

He D., Chen Y. 2006. Biogeography and molecular phylogeny of the genus Schizothorax (Teleostei: Cyprinidae) in China inferred from cytochrome $b$ sequences. Journal of Biogeography 33 (8): 1448-1460. DOI: 10.1111/j.13652699.2006.01510.x

Ihssen P.E., Booke H.E., Casselman J.M., McGlade JM., Payne N.R., Utter F.M. 1981. Stock identification: Materials and methods. Canadian Journal of Fisheries Aquatic Sciences 38 (12): 1838-1855. DOI: 10.1139/f81-230

Jager H.I., Chandler J.A., Lepla K.B., Van Winkle W. 2001. A theoretical study of river fragmentation by dams and its effect on white sturgeon populations. Environmental Biology of Fishes 60 (4): 347-361. DOI: 10.1023/ A:1011036127663

Keast A. 1978. Trophic and spatial interrelationships in the fish species of Ontario temperate lake. Environmental Biology of Fishes 3 (1): 7-31. DOI: 10.1007/BF00006306

Khan M.A., Miyan K., Khan S. 2013. Morphometric variation of snakehead fish, Channa punctatus, populations from three Indian rivers. Journal of Applied Ichthyology 29 (3): 637-642. DOI: 10.1111/j.1439-0426.2012.02058.x

Khan M.A., Sabah 2013. Length-weight and length-length relationships for five fish species from Kashmir Valley. Journal of Applied Ichthyology 29 (1): 283-284. DOI: 10.1111/j.1439-0426.2012.02061.x

Lakra W.S., Sarkar U.K. Dubey V.K., Sani R., Pandey A. 2011. River inter linking in India: status, issues, prospects and implications on aquatic ecosystems and freshwater fish diversity. Reviews in Fish Biology and Fisheries 21 (3): 463-479. DOI: 10.1007/s11160-011-9199-5

Meldgaard T., Nielsen E.E., Loeschcke V. 2003. Fragmentation by weirs in a riverine system: A study of genetic variation in time and space among populations of European grayling (Thymallus thymallus) in a Danish river system. Conservation Genetics 4 (6): 735-747. DOI: 10.1023/B:COGE.0000006115.14106.de

Mir F.A., Mir J.I., Chandra S. 2013a. Phenotypic variation in the snowtrout Schizothorax richardsonii (Gray, 1832) (Actinopterygii: Cypriniformes: Cyprinidae) from the Indian Himalayas. Contributions to Zoology 82 (3): $115-122$.

Mir J.I., Sarkar U.K., Dwivedi A.K., Gusain O.P., Jena J.K. 2013b. Stock structure analysis of Labeo rohita (Hamilton, 1822) across the Ganga basin (India) using a truss network system. Journal of Applied Ichthyology 29 (5): 1097-1103. DOI: $10.1111 /$ jai.12141

Negi R.K., Negi T. 2010. Analysis of morphometric characters of Schizothorax richardsonii (Gray, 1832) from the Uttarkashi District of Uttarakhand State, India. Journal of 
Biological Sciences 10 (6): 536-540. DOI: 10.3923/ Sunder S., Bhagat M.J. 1979. A note on the food of jbs.2010.536.540

Palma J., Andrade J.P. 2002. Morphological study of Diplodus sargus, Diplodus puntazo, and Lithognathus mormyrus (Sparidae) in the eastern Atlantic and Mediterranean Sea. Fisheries Research 57 (1): 1-8. DOI: 10.1016/S0165-7836(01)00335-6

Pandey S.K., Nautiyal P. 1997. Statistical evaluation of some meristic and morphometric characters of taxonomic significance in Schizothorax richardsonii (Gray) and Schizothorax plagiostomus (Heckel). Indian Journal of Fisheries 44 (1): 75-79.

Quilang J.P., Basiao Z.U., Pagulayan R.C., Roderos R.R., Barrios E.B. 2007. Meristic and morphometric variation in the silver perch, Leiopotherapon plumbeus (Kner, 1864), from three lakes in the Philippines. Journal of Applied Ichthyology 23 (5): 561-567. DOI: 10.1111/j.14390426.2007.00862.x

Reist J.D. 1985. An empirical evaluation of several univariate methods that adjust for size variation in morphometric data. Canadian Journal of Zoology 63 (6): 1429-1439. DOI: $10.1139 / \mathrm{z} 85-213$

Shafi S., Yousuf A.R. 2012. Length-weight relationship and condition factor of Schizothorax niger (Heckel, 1838) Misra from Dal Lake, Kashmir. International Journal of Scientific Research Publications 2 (3): 1-3.

Strauss R.E., Bookstein F.L. 1982. The truss: Body form reconstructions in morphometrics. Systematic Zoology 31 (2): 113-135. DOI: 10.1093/sysbio/31.2.113

Received: 17 January 2013

Accepted: 9 November 2013

Published electronically: 31 December 2013 drainage of Jammu Province during 1973-74. Journal of Inland Fisheries Society of India 11 (1): 117-118.

Swain D.P., Foote C.J. 1999. Stocks and chameleons: the use of phenotypic variation in stock identification. Fisheries Research 43 (1-3): 113-128. DOI: 10.1016/S01657836(99)00069-7

Szlachciak J. 2005. Morphological features of zope, Abramis ballerus, from the middle stretch of the Odra River, Poland. Acta Ichthyologica et Piscatoria 35 (2): 93-101.

Turan C. 1999. A note on the examination of morphometric differentiation among fish populations: the truss system. Turkish Journal of Zoology 23 (3): 259-263.

Więcaszek B., Krzykawski S., Antoszek A. 2007. Meristic and morphometric characters of small sandeel, Ammodytes tobianus L. (Actinopterygii: Ammodytidae), from the Gulf of Gdańsk, Baltic Sea. Acta Ichthyologica et Piscatoria 37 (1): $37-45$.

Yamamoto S., Morita K., Koizumi I., Maekawa K. 2004. Genetic differentiation of white-spotted charr (Salvelinus leucomaenis) populations after habitat fragmentation: spatial-temporal changes in gene frequencies. Conservation Genetics 5 (4): 529-538. DOI: 10.1023/B:COGE. 0000041029.38961.a0

Published electronically: 31 December 2013 